\title{
SHALLOW MOVEMENTS IN CLAY RICH ROCKS DETECTED DURING SUBNORMAL PRECIPITATION PERIOD
}

\author{
Jan BALEK ${ }^{1,2)}$ *, Jan Klimeš ${ }^{1)}$, Jan Blahůt ${ }^{1)}$, Martin Štroner ${ }^{2)}$, \\ Rudolf Urban ${ }^{2)}$ and Filip Hartvich ${ }^{1)}$ \\ 1) Institute of Rock Structure and Mechanics, The Czech Academy of Sciences, V Holešovičkách 94, 18200 Prague 8, Czech Republic \\ ${ }^{2)}$ Department of Special Geodesy, Czech Technical University in Prague, Thákurova 6, 16629 Prague 6, Czech Republic \\ *Corresponding author's e-mail: balek@irsm.cas.cz
}

\section{ARTICLE INFO}

Article history:

Received 24 Jane 2019

Accepted 29 August 2019

Available online 9 October 2019

Keywords:

Landslide

SAA sensor

MEMS

Monitoring

Displacements

Precipitation

Temperature

\begin{abstract}
The paper aims at the evaluation of the landslide movement monitoring near Třebenice town in the České středohoří hilly land, Czechia. The monitored period between May of 2017 and January 2019 is characterized by negative effective precipitations and continually decreasing ground water levels in conditions of Cretaceous sedimentary rocks of different permeability. In the spring of 2017, the SAA (ShapeAccelArray) sensor was installed into the borehole placed one the most active part of the landslide area. Sensor was stabilized in $16 \mathrm{~m}$ depth, $2.5 \mathrm{~m}$ under the deepest sliding plane. SAA sensor automatically registers absolute values of displacements in different layers. The results indicate a slow movement above the shallower (4 $\mathrm{m}$ deep) sliding plane, with velocities changing significantly based on annual period from $3 \mathrm{~mm} / \mathrm{month}$ during spring to $0 \mathrm{~mm}$ during late summer and autumn months. Measured displacements were confronted with course of GWLs, temperature and potential effective precipitation, to discover causes of the reversible movement.
\end{abstract}

\section{INTRODUCTION}

Movement rates of landslides are important intensity characteristics used to determine hazard levels (Lateltin et al., 2005; Lu et al., 2014). Despite the fast development and growing popularity of satellite-based landslide movements detection techniques, which are capable of providing information across vast regions without necessity of costly in-situ installations and with high temporal frequency (less than 3 days, Casagli et al., 2017), reliable hazard assessment or early warning applications still require in-situ verifications of the remotely sensed information (Strozzi et al., 2018). It is one more reason why automatic capturing of the insitu landslide movement data and their real- or nearreal-time transmission to the user, became a basic requirement of any monitoring set-up (Blahut et al., 2018). Resulting that a large part of geotechnical measurements can be performed automatically using variety of simple (Klimeš et al., 2012) or complex sensors (Pánek and Klimeš, 2016) providing information about surface or sub-surface movements. One of the preferable methods for the sub-surface landslide monitoring is the inclinometric measurements in the boreholes, which can precisely identify depth, velocity and direction of movements along even multiple sliding planes. The current developments in the borehole monitoring automation aims on the permanent positioning of several sensors in a single borehole installed in several selected depths or with regular spacing (Foglino et al., 2006; Measurand, 2014). Such solution can be used to monitor deformations in a comprehensive way across depth profile of several tens of meters with data transmission and processing in a real-time, which is highly desirable for early warning purposes and also provides information for comprehensive assessment of the relationship between triggers and landslide movements with high vertical resolution.

Instruments allowing automated ground water levels (GWLs) and subsurface landslide movement data logging, at high temporal resolution, were installed at a site Třebenice with long-term monitoring history in the NW Czechia (Fig. 2). The selection of the installation site was based on detailed morphological and geological information about the monitored landslide (Novotný and Kobr, 2008). Monitoring results of the 1.5 years (1.5.2017 13.12.2018) during which no extreme precipitation events occurred are presented and compared to the precipitations, air and soil temperatures to assess drivers of the detected movements. 


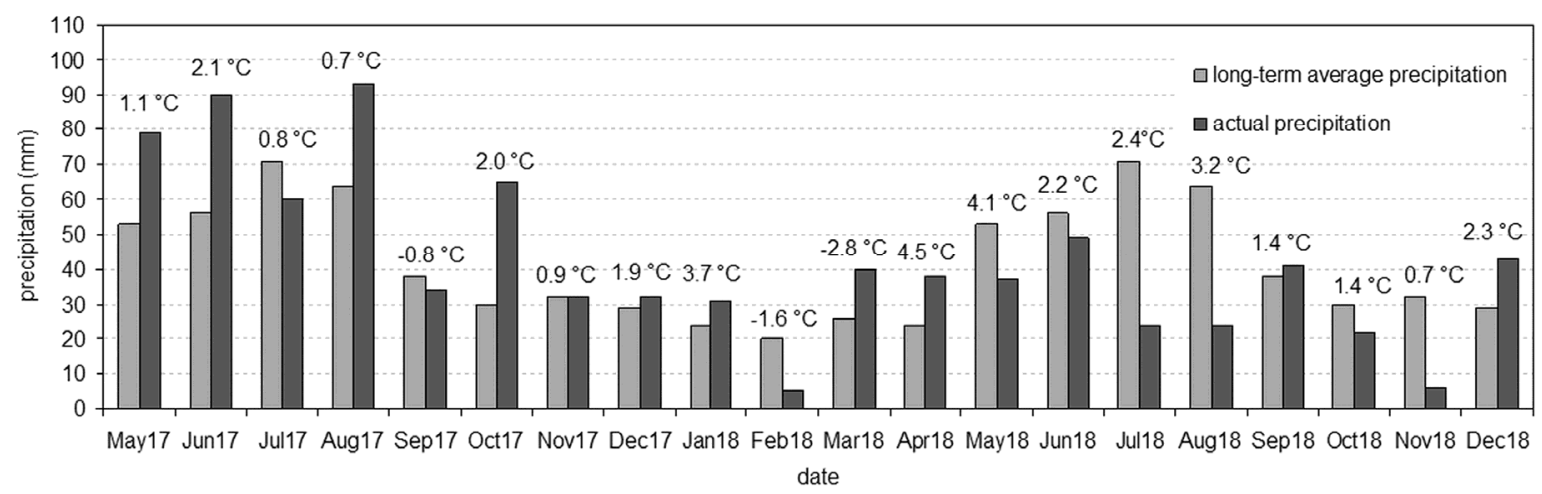

Fig. 1 The long-term (1981 - 2010) monthly precipitation averages and deviations from average monthly temperatures (1981 - 2010, numbers above precipitation bars) measured at the meteorological station (Doksany, $13 \mathrm{~km}$ WNW from the studied site) operated by the Czech Hydrometeorological Institute (CHMI). Actual precipitations were measured during the observation period by the automated meteorological station $2 \mathrm{~km}$ WNW from the study site.

\section{STUDY SITE}

The Třebenice complex landslide developed in the Late Cretaceous poorly cemented sediments, which cover the south edge of the Tertiary volcanic complex of the České strredohoří is a hilly land built by Tertiary volcanites overlaying Cretaceous sediments (claystones and marlstones). In the studied locality tertiary volcanities form local peaks and slopes are formed only claystones and marlstones. The recent relief is strongly affected by intense Quaternary denudation and erosion removing less competent Cretaceous and Quaternary sediments and forming gentle, wide valleys while leaving hills formed by more resistant Tertiary volcanic rocks (Novotný and Kobr, 2008) dominating the landscape. The studied landslide complex is located on the gentle, southeast slope of rounded peak Malá Kozí Horka (329 m a.s.1.) composed by isolated volcanic body built by olivine nephelinite and nephelitine basanites (Voráček, 1991). The Cretaceous rocks of the complex landslide are represented by a monotonous sequence of Late Turonian to Coniacian calcareous claystones to marlstones (Zoubek and Škvor et al., 1963) which are highly susceptible to volume changes caused by soil water saturation (Rybář, 2007). Hydrogeological monitoring showed that ground water flows preferentially through higher permeability zone 8 to $10 \mathrm{~m}$ below the surface enclosed by rock material with 1-2 orders lower hydraulic conductivity (Novotný and Kobr, 2008).

The study site is located in the warm climatic region of Czechia defined by climatic characteristics measured in 1961 - 2000 (Vondráková et al., 2013) using the classification scheme of Quitt (1971). This region is characterized by lower precipitations during vegetation period $(300-350 \mathrm{~mm})$ and higher mean January $\left(-2\right.$ to $\left.-3{ }^{\circ} \mathrm{C}\right)$ and July $\left(19\right.$ to $\left.20{ }^{\circ} \mathrm{C}\right)$ temperatures. Comparison of the long-term (1981 2010) monthly precipitation averages and average temperatures with actual precipitations measured during the observation period (Fig. 1) show above average precipitation during the vegetation period 2017.

The whole landslide was firstly identified in 1916 (Novotný, 2002) and its recently mapped total area is $28,000 \mathrm{~m}^{2}$ with the mean slope angle of $12^{\circ}$ and the altitude between 240 and $285 \mathrm{~m}$ a.s.1. It is formed by several partial landslides which have been re-activated several times in the recent history (Balek et al., 2015). The partial landslide described in this work has complex sliding surface up to $5 \mathrm{~m}$ deep and has been monitored since 1994 (Novotný, 1998; Novotný, 2002; A in Fig. 2). The monitoring consists of two profiles controlled with portable tape extensometer and various hydrogeological observation boreholes where GWLs were manually recorded and different types of piezometers were installed for several years period (Novotný and Kobr, 2008; Novotný et al., 2006). Detected seasonal creep (Novotný, 2002) and repeated major movement phases (1938, 1939, 1970, 1981; Balek et al., 2015) of this landslide suggest that its stability is near the equilibrium state with periods of unstable conditions. This is why the studied landslide has been partly stabilized in the early $1980^{\prime}$, with measures focusing on the operability of the railroad, while omitting the stability of the local asphalt road. The main stabilization measure consisted of the $12 \mathrm{~m}$ deep pile wall supporting the railroad and preventing water infiltration to the most active landslide part (A in Fig. 2) above the railroad by constructing drainage channels and water infiltration walls (Zuzánek and Vaněček, 1982; Ladman and Zuzánek, 1970).

\section{METHODS}

\section{SHAPEACCELARRAY (SAA) SENSOR}

The SAA is an array of solid segments $(0.305 \mathrm{~m}$ of length with three bi-axial MEMS accelerometers) and flexible joints (with maximum bending of $45^{\circ}$ ) which register relative position of the individual 


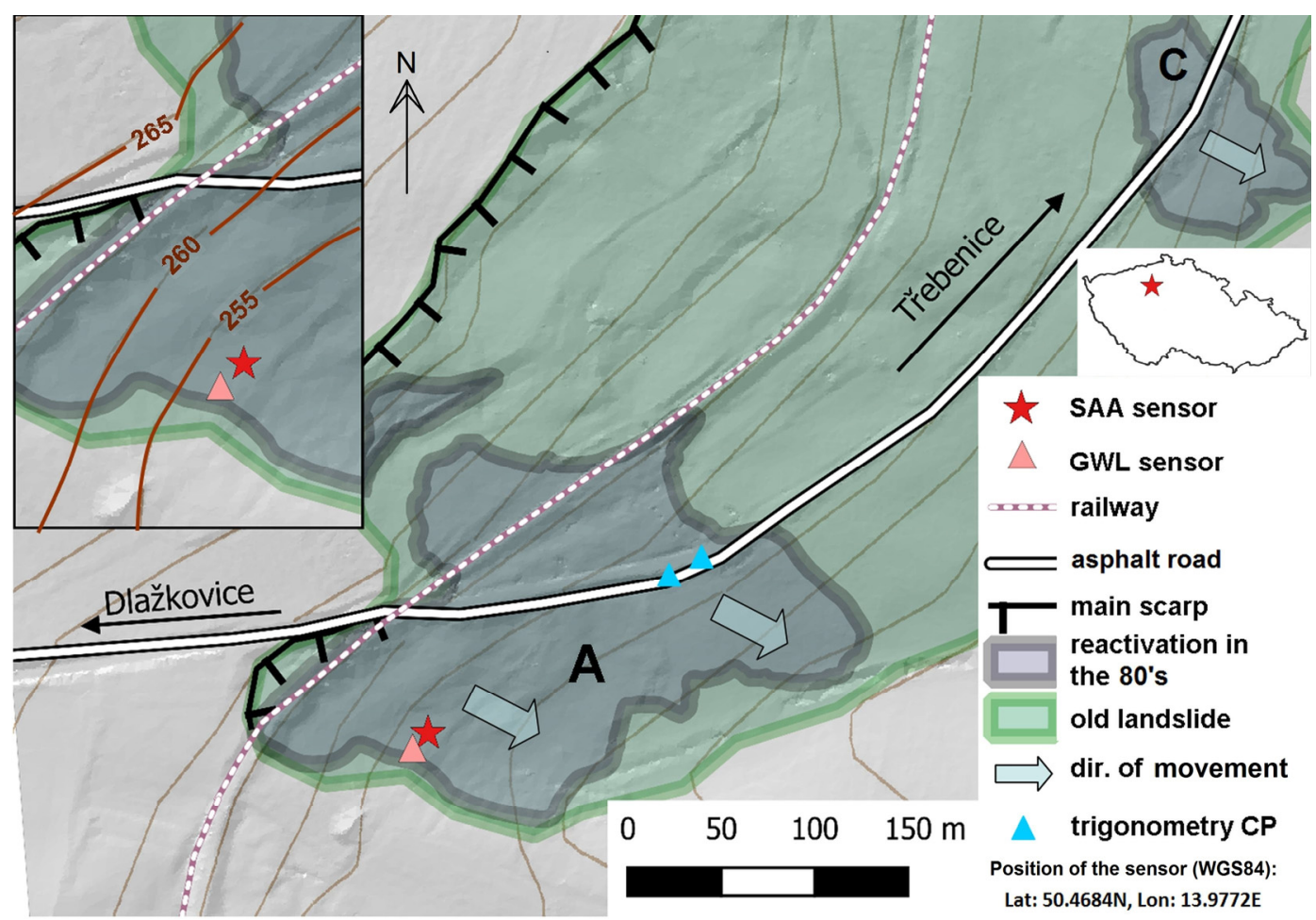

Fig. 2 Location map shows old landslide with younger reactivations A, C in Rybár (1983) (B is located outside the map view) from the 1981 and 1982 and location of the monitoring equipment (SAA - ShapeAccelArray, GWL - ground water level sensor, CP - control point, dir. - direction).
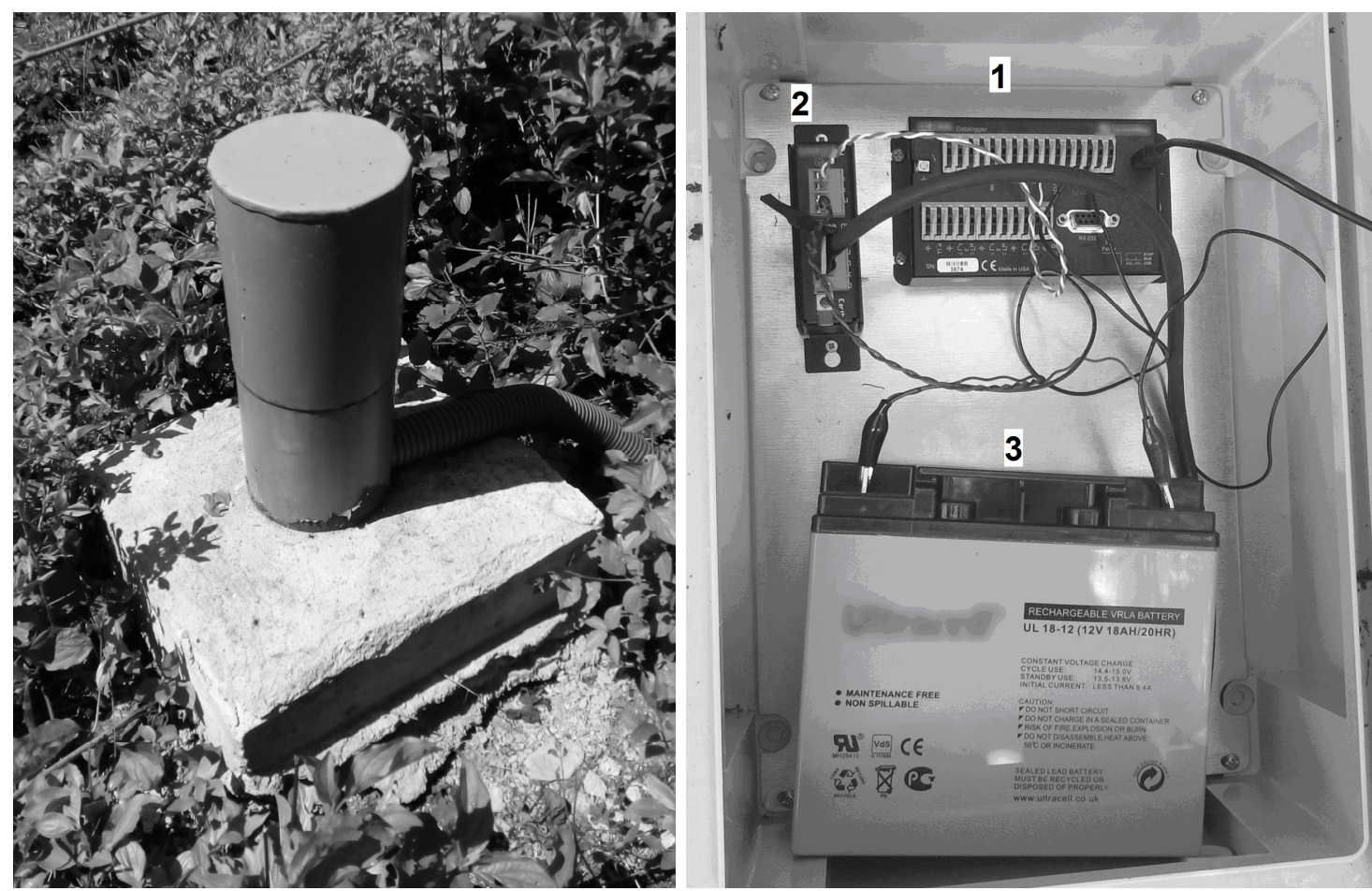

Fig. 3 Borehole with data cable placed in protective casing (left) and wiring case (right); 1 - datalogger CR300, 2 - SAA232 voltage stabilization unit, $3-12 \mathrm{~V}$ battery with a capacity of $18 \mathrm{Ah}$ ). 
segments with respect to the direction of gravity (Measurand, 2014). Measured data allows calculation of the joints positions relative to one of the endpoints of the array. The array contains seven temperature sensors $(1.4 \mathrm{~m}, 3.8 \mathrm{~m}, 6.2 \mathrm{~m}, 8.7 \mathrm{~m}, 11.1 \mathrm{~m}, 13.6 \mathrm{~m}$, $16.0 \mathrm{~m}$ under the surface) used to correct length of the segments affected by thermal expansion, compensate the temperature drift of the accelerometers and characterize underground environment. Integrated microprocessor digitizes the measurements, which are then exported to the external recording and control unit (universal CR300 datalogger, Fig. 3 right).

The device was tested in laboratory conditions to explore its capabilities and limits (Balek et. al., 2016; Urban et. al., 2016). The sensor accuracy of $0.05 \mathrm{~mm}$ per segment was achieved under small maximum sensor deformations up to $10^{-2} \mathrm{~m}$, which were expected at the installation site. Thus the standard deviation in joint position of the used array is $0.35 \mathrm{~mm}$ with the decreasing accuracy from the bottom of the borehole (depth of $15.2 \mathrm{~m}$ ) to the end joint near the surface (depth of $0.8 \mathrm{~m}$ ).

\section{SAA SENSOR INSTALLATION AND DATA PROCESSING}

The SAA sensor was placed into a $16 \mathrm{~m}$ deep borehole located at the toe of the partially active landslide (Fig. 2). The drilling core was documented (November 2016, Fig. 4) and the borehole was equiped with PVC-U pipe fixed with a claycement/bentonite mixture enclosing the sensor (16.4.2017) in a way that its $+Y$ axes is oriented down the slope $\left(\mathrm{SE}, 150^{\circ}\right)$ and $+\mathrm{X}$ axes to the southwest $\left(240^{\circ}\right)$.

The optimal function of the sensor requires a very precise voltage which is achieved by the SAA232 voltage stabilization unit to value of $13.5 \mathrm{~V}$ (Fig. $3 \mathrm{~b}$ right). Depending on ambient temperature, the battery is capable of powering the device for 2 to 3 months recording an average value of 1000 readings taken every $15 \mathrm{~min}$. The measured values are downloaded from the datalogger using the PC200W utility and stored in *.dat file (text format) where each row represents one recorded value. The raw measurements are processed and calibrated in the raw2data utility to obtain positions of the joints in the device coordinate system (e.g. absolute shape). The sensor's movements are computed (SAAView and Matlab) as variations of its absolute shape to the selected reference measurement (1.5.2017).

\section{MONITORING OF THE ENVIRONMENTAL CONDITIONS}

Fluctuations of maximum GWLs and amount of effective precipitations potentially recharging the unsaturated zone and increasing pore pressures are factors often related with landslide occurrence or movement activity. The GWLs were recorded in $9.5 \mathrm{~m}$ deep hydrological observation borehole located just $10 \mathrm{~m} \mathrm{SW}$ from the SAA sensor in the same altitude. It was equipped by hydrostatic hydro logger
TSH22 (0-10 m measurement range with accuracy of $0.1 \%$ of the measurement range) registering GWLs every 1 hour.

Unlike in the case of Novotný et al. (2006), no direct measurements of soil saturation were available, thus we used meteorological variables (e.g. precipitation, temperature, humidity) to estimate potential effective precipitation. Temperature, precipitation and humidity were measured by automatic meteorological station situated $2 \mathrm{~km}$ ENE from the landslide monitoring sensors. Meteorological variables were recorded within 10 minutes interval, but their daily means or sums were processed to compute potential effective precipitation defined as difference of the total precipitations and potential evapotranspiration. It does not describe the real water volume entering the unsaturated zone, but serves as an indicator of hydrological conditions suitable for comparison of observation months. Two calculation methods suitable for areas with dense vegetation cover were applied to estimate daily sums of potential evapotranspiration. Linacre equation (Linacre, 1977) allows estimating potential evapotranspiration only using measured temperature (1), while Ivanov (1954) equation is based on monthly averages of humidity and temperature (2).

$P E T=\frac{\left[500 \cdot T_{\mathrm{m}} /(100-\phi)\right]+15\left(T-T_{d}\right)}{T-80} ;$

$T_{\mathrm{m}}=T+0.006 \cdot \mathrm{h}$

where:

PET ... potential evapotranspiration $[\mathrm{mm} / \mathrm{d}]$

$T$... average temperature $\left[{ }^{\circ} \mathrm{C}\right]$

$\varphi$... geographic latitude [degrees]

$T_{d} \ldots$ average temperature of dew point $\left[{ }^{\circ} \mathrm{C}\right]$

h ... elevation

$P E T=0.0018 \cdot(25+T)^{2} \cdot(100-r h)$

where:

PET ... potential evapotranspiration [mm/month]

$T$... average temperature per month $\left[{ }^{\circ} \mathrm{C}\right]$

$r h$... average humidity per month [\%]

\section{RESULTS}

Analysis of core drilling samples suggests two sliding planes approximately at $4.2 \mathrm{~m}$ and $13.5 \mathrm{~m}$ below the surface (Fig. 4). The shallower one identified by sliding marks inside the drilled core represents the slip plane reactivated during 1981 and 1982 partial landslide movements (Fig. 2) and corresponds to their previously reported depths (Rybár, 1983). It is located at lithological boundary of plastic clay with rock fragments and compact, hard clay. The deeper, suggested sliding plane is represented by extremely wet and soft clay or weathered clay stones where no sliding marks were identified. It could represent slip surface of the older and larger landslide (Pašek, 1964). 

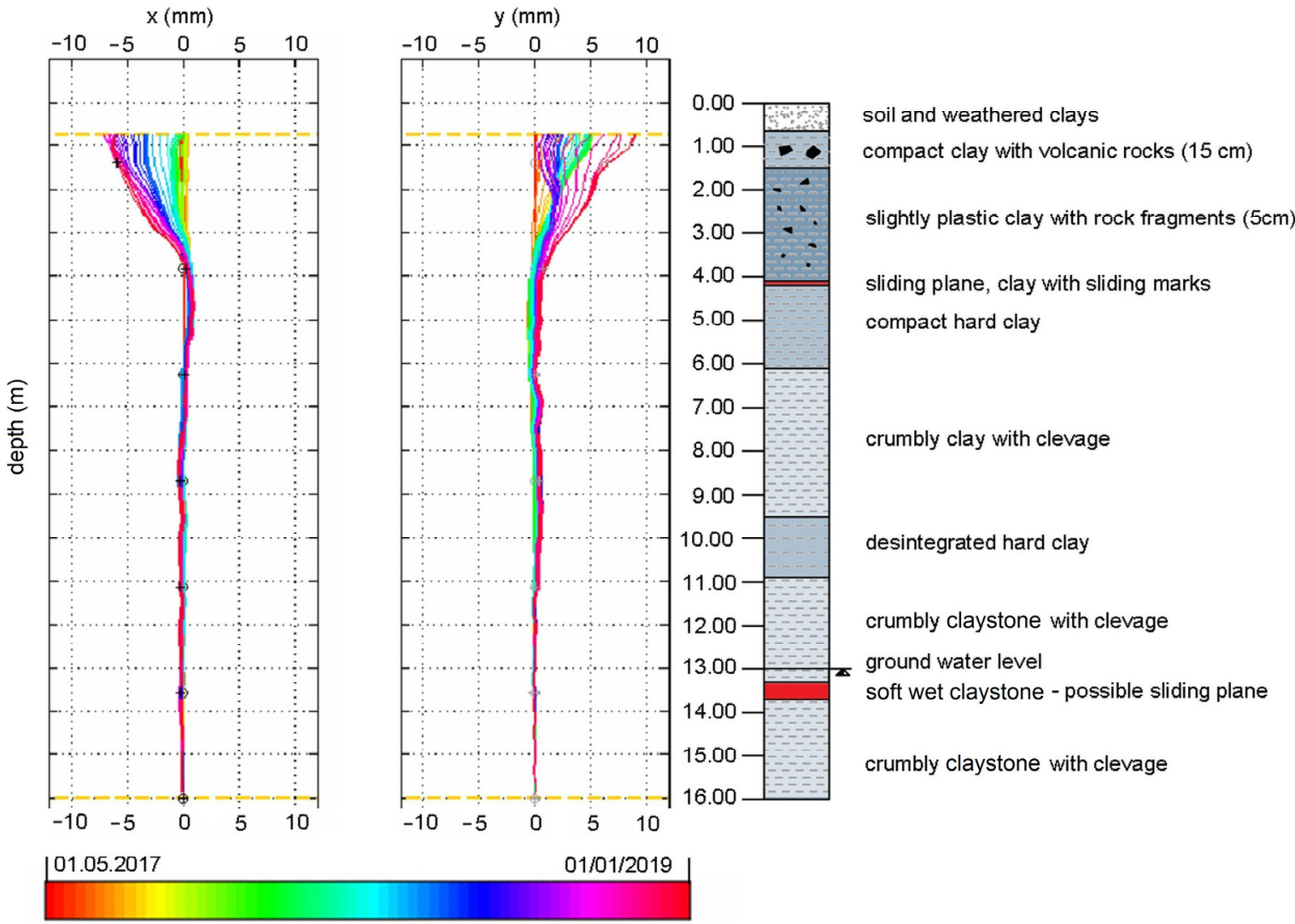

01.05.2017

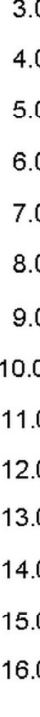

slightly plastic clay with rock fragments $(5 \mathrm{~cm})$

sliding plane, clay with sliding marks

compact hard clay

6.00

7.00

$8.00-$

$9.00-$

$10.00 \quad$ desintegrated hard clay

11.00

12.00

13.00

ground water level

soft wet claystone - possible sliding plane

$15.00-$

crumbly claystone with clevage

Fig. 4 Deformation of the sensor in time (left) 14 days step (1.5.2017 - 1.1.2019), brown solid line shows surface level. Vertical profile based on core drilling log (right).
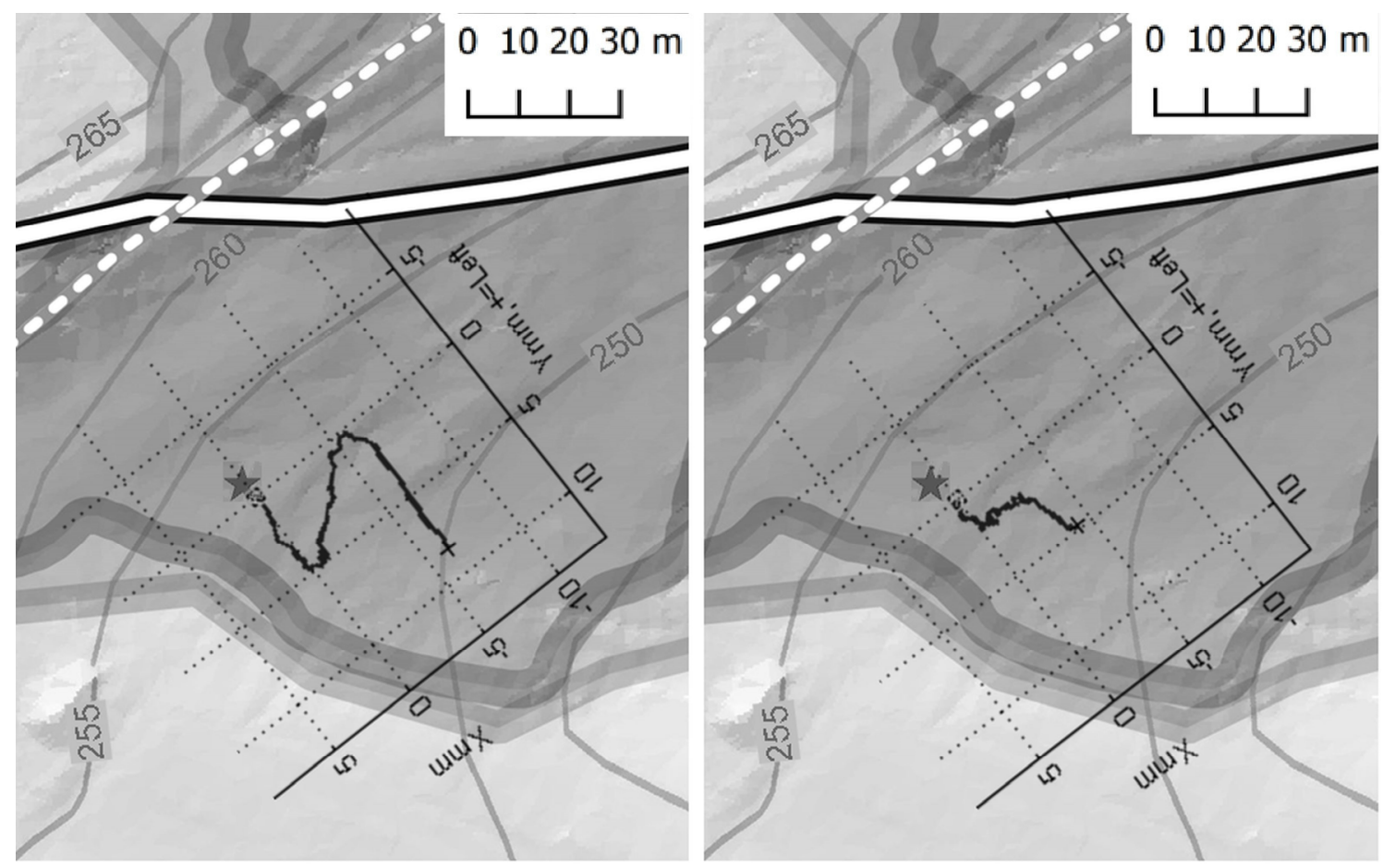

Fig. 5 Polar plots (not at map scale) show the horizontal displacement of joints in the depth of $1.1 \mathrm{~m}$ (left) and $2.3 \mathrm{~m}$ (right). The star represents initial position on 1.5.2017, while the black cross shows position on 1.1.2019. 

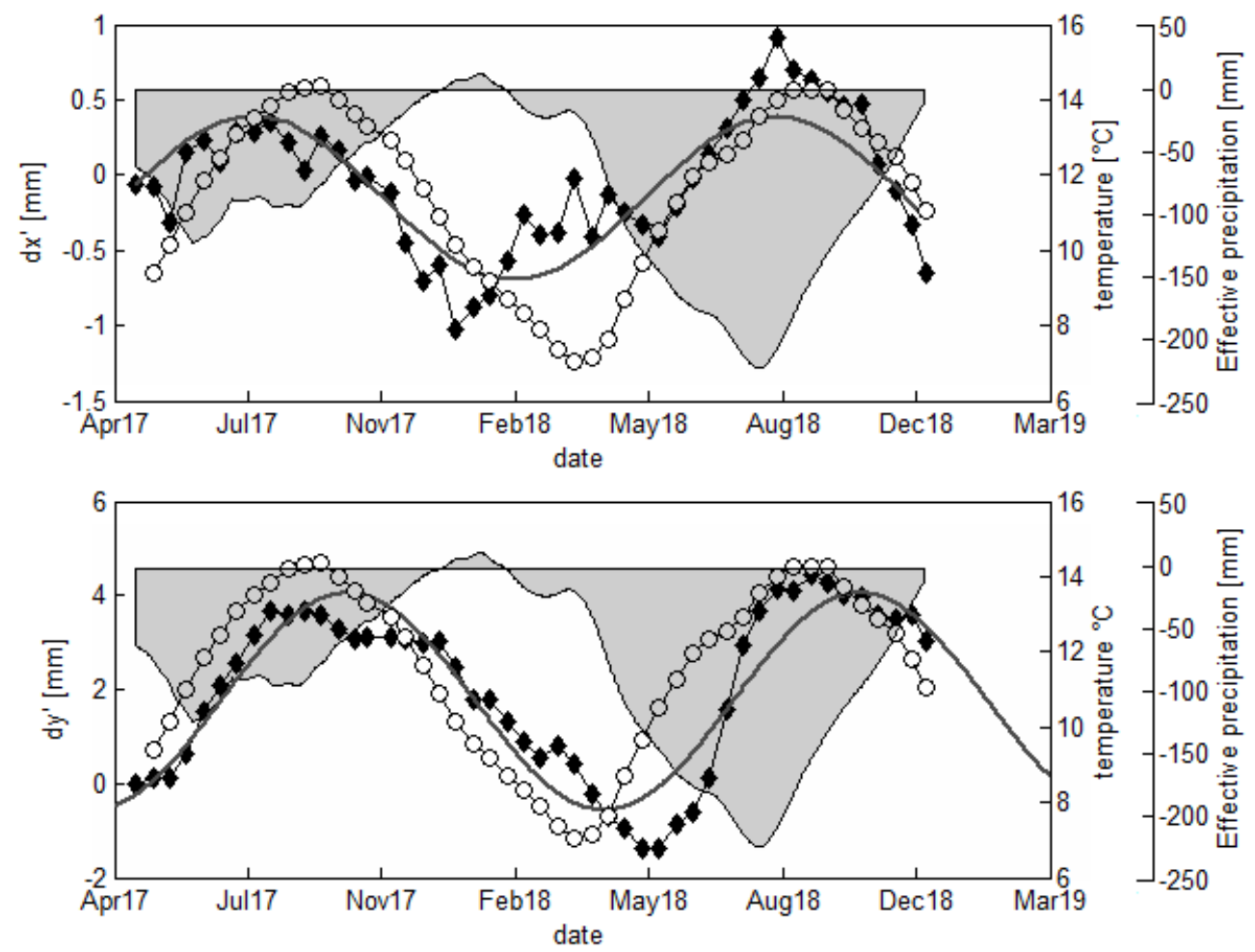

Fig. 6 Displacement components (dx' component parallel with the direction of the movement - up, dy' component perpendicular to the direction of the movement - down) and temperature in the depth of $1.1 \mathrm{~m}$ are shown along with the potential effective precipitation. Black filled diamonds - displacements, white circles - temperature measured by the SAA sensor in $1.1 \mathrm{~m}$ depth, gray solid line - Fourier fit of displacements, filled gray area - potential effective precipitation according to the Linacre (1977).

\section{MOVEMENTS CAPTURED BY THE SAA SENSOR}

The high frequency readings were accompanied with random noise of the MEMS accelerometers measurements. Its standard deviation was estimated using daily moving averages to be $0.16 \mathrm{~mm}$ for the uppermost joint of the SAA array (e.g. $0.02 \mathrm{~mm}$ per segment joint). It is in consistence with results of laboratory testing of the device (Urban et. al., 2016).

The monitoring captured horizontal displacements in order of $5 \mathrm{~mm} /$ year, which is well above the accuracy limits of the sensor (Urban et al., 2016). The acquired deformations along the depth profile identified the shallow sliding plane at approximately $3.8 \mathrm{~m}$, while no activity was detected on the deeper sliding plane (at $13.5 \mathrm{~m}$, Fig. 4). Highest movement activity was recorded by the segments closer to the surface in the direction striking along the slope (y in Fig. 4).

The polar plots show displacements of the sensor joints in $1.1 \mathrm{~m}$ and $2.3 \mathrm{~m}$ depths (Fig. 5). Downslope, irreversible movements reached $8 \mathrm{~mm}$ and $5 \mathrm{~mm}$ respectively. While the reversible movement component is perpendicular to the local slope it has similar magnitude at $1.1 \mathrm{~m}$ depth (5 to $8 \mathrm{~mm}$ ), it is reduced to 2 or $3 \mathrm{~mm}$ in $2.3 \mathrm{~m}$.
We estimated the periodicity of the reversible movements and related them with available environmental characteristics to explain their possible drivers. For this purpose, components of relative displacements $(\mathrm{X})$ at the $1.1 \mathrm{~m}$ depth were rotated so, the direction of movement was aligned with $\mathrm{x}$ axes of the local coordinate system (3) and the direction of movement was estimated using linear regression.

$X^{\prime}=R \cdot X$

Fourier model was fitted to estimate characteristics of the periodic component, specifically the $1^{\text {st }}$ harmonics. Period of the reversible movements perpendicular to the downslope movement direction was estimated to 380 days \pm 19 days (dy' in Fig. 6) giving roughly the annual period. Relatively high inaccuracy of the period estimation is given by short data record (less than two annual periods). The peak amplitude was estimated to be $2.2 \mathrm{~mm}$. The period of the reversible movements in the downslope direction (dx' in Fig. 6) was estimated to 390 days ( \pm 30 days) with peak amplitude of $0.5 \mathrm{~mm}$.

Figure 6 also well illustrates the underground annual temperature variations measured by the SAA sensor. Its annual peak amplitude at $1.1 \mathrm{~m}$ depth is 


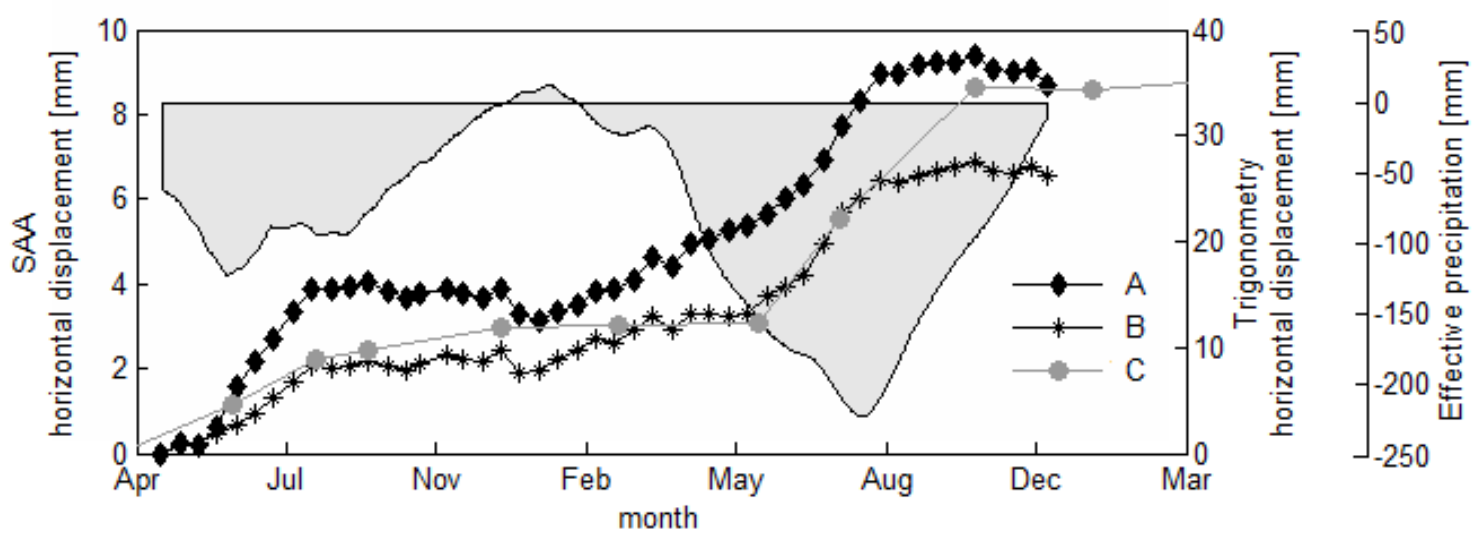

Fig. 7 Total horizontal displacements detected by the SAA sensor in the depths of $1.1 \mathrm{~m}(\mathrm{~A})$ and $2.3 \mathrm{~m}$ (B) during April 2017 - December 2018 are shown along with the surface movements detected by trigonometric measurements (C) during April 2013 - December 2015 by Balek et al. (2015).

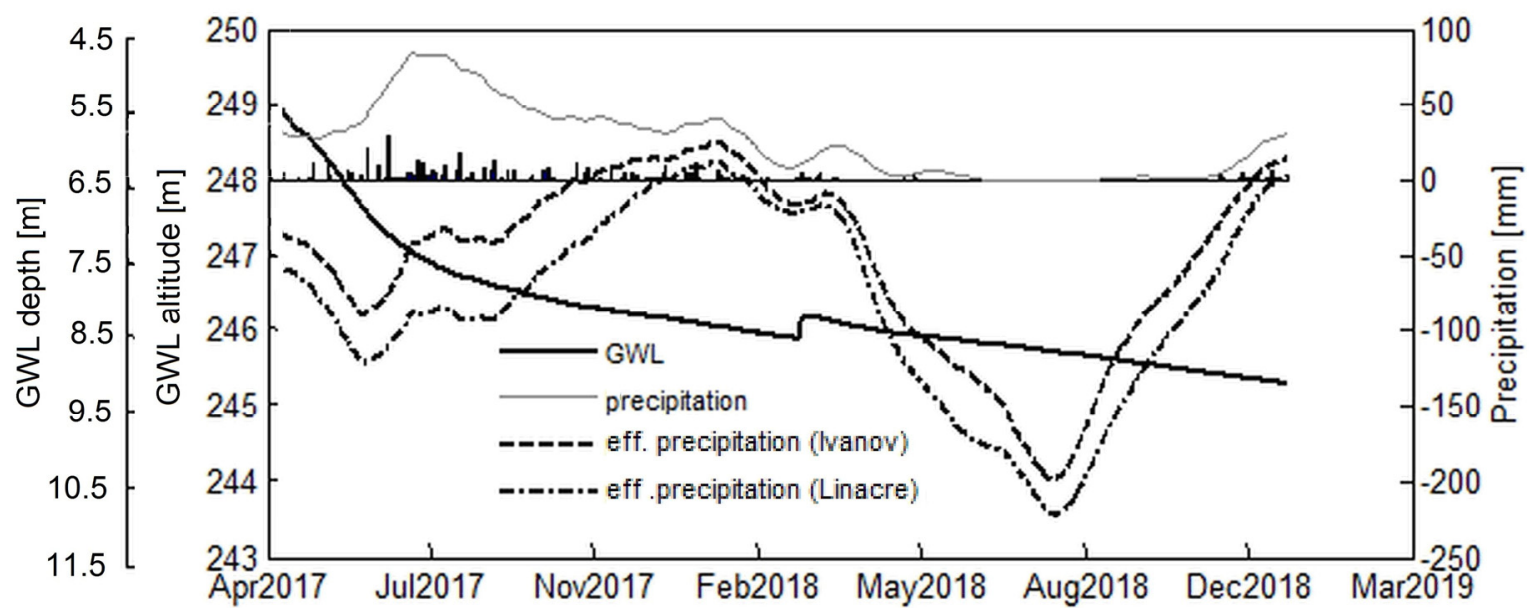

Fig. 8 Accumulated 30 days precipitation and potential effective precipitation and GWLs during 1.5. 20171.1.2019 period.

about $3.5{ }^{\circ} \mathrm{C}$ decreasing to $1{ }^{\circ} \mathrm{C}$ near the first sliding plane $(3.8 \mathrm{~m})$ and less than $0.5^{\circ} \mathrm{C}$ below $8 \mathrm{~m}$. The annual temperatures closely resemble the movement components course, while the potential effective precipitation seems phase shifted by several months.

Total displacement of the SAA sensor joints shows acceleration during spring and early summer (Fig. 7), which does not seem to be well explained by the precipitation record. The May - July 2017 movement acceleration could be related with the beginning of the increasing potential effective precipitations, but the next seasonal movement acceleration (May - July 2018) occurred during decreasing effective precipitation period. Similarly biased is comparison of the displacements with the sum of differences between actual and long-term average monthly precipitations. The annual movement trend was detected also during surface trigonometric measurements in 2013 and 2016 (Balek et al., 2015, Fig. 7). Displacements were measured in local trigonometric network, which had base on the stabilized railway line body. Unfortunately the base points were destroyed during the railway line reconstruction in 2015, so it was not possible to compare identical time periods.

\section{PRECIPITATION AND GWL}

The largest amount of precipitation falls during summer as it shows the monthly accumulation totals, while the potential effective precipitation is highest during the winter months (Fig. 8). These results are comparable with Novotný et al. (2006) and show strong annual periodicity of the precipitations.

The GWL had been decreasing during the entire monitoring period (1.5.2017 - 1.1.2019) and shows no annual periodicity. The small peak in March 2018 represents 0.5 meter GWL rise and could be possibly related with the peak of potential effective precipitation which occurred about 2 months earlier (Fig. 8).

\section{DISCUSSION}

The SAA sensor detected shallow movements (up to $4 \mathrm{~m}$ depth) with clear annual trend of acceleration during spring and early summer (March July) followed by period of several months with 
almost no detectable movements. This movement pattern occurs even during period with no extreme precipitation events and mostly negative effective precipitations and with the GWLs permanently decreasing and situated $1.2 \mathrm{~m}$ to $4.5 \mathrm{~m}$ below the detected sliding plane. The observed pattern is probably a result of the several months delay of the peak potential effective precipitation which occurs during winters (December - January) and which is followed by reduction in soil suction which may reach $0 \mathrm{kPa}$ in the depth of $1 \mathrm{~m}$ (from February to May) or 10 to $-20 \mathrm{kPa}$ a the depth of $2 \mathrm{~m}$ with the peak in May (Novotný et al., 2006). It is likely that the advance of the minimum suction below $2 \mathrm{~m}$ depth is further delayed, which could explain the peak horizontal displacement detected in June - July. Magnitude of the total horizontal movements was not affected by the above average precipitation during the summer of 2017 as the potential effective precipitation remained still well below 0 value.

The SAA sensor showed periodic movements with the period estimated to be one year. These reversible movements could be caused by factors with an annual periodicity like temperature variations or variations in soil saturation. They are not caused by fluctuations of GWL since it is permanently decreasing and has no annual periodicity in the evaluated period and also because the GWL is below the maximum depth of the detected movements. Changes in the speed of the movement with an annual periodicity are in consistence with previous research on this locality (Novotný et. al., 2008; Balek et. al., 2015). Based on the results of the monitoring, sliding seems to be more complicated than downslope movement with variable velocity. We assume that movements and volume changes of soils are strongly connected and that volume changes have important influence on slope movement under the studied conditions.

However it is likely, that part of these movements can be caused by insufficient compensation of the temperature variations on measurements of the MEMS accelerometers. With regard to the published results of former testing, we assume that this effect had significantly minor importance in this case. Beran et al. (2014) presented result of the experiment when temperature fluctuations in range of $25^{\circ} \mathrm{C}$ caused submilimeter errors in the position at the end of $4 \mathrm{~m}$ long SAA sensor, which were characterized by standard deviation of $0.6 \mathrm{~mm}$. In our case SAA sensor is $15 \mathrm{~m}$ long, but temperature changes affect significantly no more than top 4 meters of the sensor. Moreover, temperature variations are 3-4times lower than in the experiment mentioned above, therefore, a much lower influence of temperature changes on measured shifts can be expected.

MEMS accelerometers measurements also show significant random noise, which can be easily reduced by averaging. Therefore it is convenient to capture data with several times higher frequency than is the frequency needed. Especially, when magnitude of the movements is very small like in this case. Based on the data captured in the field, random noise was described by standard deviation of $0.02 \mathrm{~mm} / \mathrm{segment}$, represented by $0.16 \mathrm{~mm}$ at the uppermost $(0.8 \mathrm{~m}$ below ground surface) joint of the sensor. It is in consistence with results of previous laboratory tests and it represents quite large number compared to overall accuracy of the sensor estimated in the laboratory (standard deviation of $0.05 \mathrm{~mm} / \mathrm{segment}$ resp. $0.35 \mathrm{~mm}$ at the end joint of the sensor).

\section{CONCLUSIONS}

Movements of shallow (up to $4.2 \mathrm{~m}$ ), repeatedly active landslide in clays and weathered clay stones were monitored using SAA sensor during period (May 2017 - January 2019) of mostly negative effective precipitations, no extreme weather events and decreasing ground water level situated at least $1.2 \mathrm{~m}$ below its sliding plane. It detected reversible, horizontal movements perpendicular to the slope with $4.4 \mathrm{~mm}$ peak-to-peak amplitude near ( $1.1 \mathrm{~m}$ depth) the ground surface and irreversible horizontal movements along the slope with magnitude $8 \mathrm{~mm}$ totally. These movements do not represent slips on a sliding plane but movements of the reworked landslide material and their magnitude is decreasing with the depth. The magnitude of the reversible movements is so small, that is unlikely to significantly affect local infrastructure such as roads or railways as they are constructed to withstand reversible changes in order of millimeters. Nevertheless, we may speculate that they could negatively affect the service life of underground lines (e.g. water pipes). The irreversible movement along the slope could accumulate with time into the deformations which may result into infrastructure damage.

The obtained results confirm high susceptibility of landslide material to slope movements which does not necessarily need to be related with the historical sliding plane, but are probably governed by delayed effects of soil saturation. Further research is needed to determine if the observed reversible movements near the ground surface are unique to the slopes affected by shallow landsliding or if they may occur under similar geological and morphological conditions also on slopes where no historical landslides were identified.

\section{ACKNOWLEDGEMENTS}

This research was funded by: Grant Agency of CTU in Prague - grant number SGS19/047/OHK1/1T/11, long-term conceptual development research organisation RVO: 67985891 and the project CzechGeo/EPOS - Sci CZ.02.1.01/0.0/0.0/16_013/0001800 and the project RINGEN+ (CZ.02.1.01/0.0/0.0/16_013/0001792). 


\section{REFERENCES}

Balek, J., Marek, T. and Kadlečík, P.: 2015, Historical and current evolution of the landslide area near Třebenice. Geoscience Research Reports, 2014, 51-54. DOI: 10.3140/zpravy.geol.2014.29

Balek, J., Urban, R. and Štroner, M.: 2016, Laboratory testing of the precision and accuracy of the ShapeAccelArray sensor in horizontal installation. 16th International Multidisciplinary Scientific GeoConference SGEM 2016. SGEM 2016 Conference Proceedings. June 28 - July 6, 2016, Book1, 1, 871878.

Beran, T., Danisch, L., Chrzanowski, A. and Bazanowski, M.: 2014, Measurement of deformations by MEMS arrays. Verified at Sub-millimetre Level Using Robotic Total Stations. Geoinformatics FCE CTU, 12, 34-40.

Blahůt, J., Baroň, I., Sokol', L., Meletlidis, S., Klimeš, J., Rowberry, M., Melichar, R., García-Cañada, L. and Martí, X.: 2018, Large landslide stress states calculated during extreme climatic and tectonic events on El Hierro, Canary Islands. Landslides, 15, 1801804. DOI: $10.1007 / \mathrm{s} 10346-018-0993-1$

Casagli, N., Frodella, W., Morelli, S., Tofani, V., Ciampalini, A., Intrieri, E., Raspini, F., Rossi, G., Tanteri, L. and Lu, P.: 2017. Spaceborne, UAV and ground-based remote sensing techniques for landslide mapping, monitoring and early warning. Geoenvironmental Disasters, 4, 9.

DOI: 10.1186/s40677-017-0073-1

Foglino, L., Lovisolo, M. and Della Giusta, A.: 2006, Contribution of DMS monitoring systems in the analysis of slide micro-movements for early warning management, risk assesment and evaluation of mitigating actions. Geophys. Res. Abstr., 8, 06122.

Ivanov, N.N.: 1954, The determination of potential evapotranspiration. Izvestiia Vsesoiuznogo Geografficheskogo Obschestva, 86, 2. (NNA.900626.0209).

Klimeš, J., Rowberry, M.D., Blahůt, J., Briestenský, M., Hartvich, F., Košták, B., Rybáŕ, J., Stemberk, J. and Štěpančíkova, P.: 2012, The monitoring of slowmoving landslides and assessment of stabilisation measures using an optical-mechanical crack gauge. Landslides, 9, 407-415. DOI:10.1007/s10346-011-0306-4

Ladman, Z. and Zuzánek, B.: 1970, Final report of geological survey: Třebenice - remediation measures on railway body in $6.9-7.0 \mathrm{~km}$ of Čížkovice-Obrnice railroad, n. p., Praha. Dubí u Teplic, (in Czech).

Lateltin, O., Haemmig, C., Raetzo, H. and Bonnard, C.: 2005, Landslide risk management in Switzerland. Landslides, 2, 4, 313-320. DOI: $10.1007 / \mathrm{s} 10346-005-0018-8$

Linacre, E.T.: 1977, A simple formula for estimating evaporation rates in various climates, using temperature data alone. J. Agric. Meteorol., 18, 409424. DOI: 10.1016/0002-1571(77)90007-3

Lu, P., Catani, F., Tofani, V. and Casagli, N.: 2014, Quantitative hazard and risk assessment for slowmoving landslides from Persistent Scatterer Interferometry. Landslides, 11, 685-696. DOI: 10.1007/s10346-013-0432-2

Measurand: 2014, SAAF technical specification. Available from:

http://www.measurandgeotechnical.com/docs/saafspecificati onmodel00341031.pdf
Novotný, J.: 1998, First results of monitoring on Třebenice Landslide in Czech Republic in Europe. Proceeding 8th International IAEG Congress, Rotterdam, Balkema, 1669-1676, (in Czech).

Novotný, J.: 2002, Analysis of water effect on slope stability in clayey rocks. Acta Montana, 10, (127), 7-47.

Novotný, J., Kohut, M., Možný, M., Herbstová V.: 2006, Climatic impact to water conditions in the unsaturated and saturated zone of clayey rocks. $34^{\text {th }}$ Congress of International Association of Hydrogeologists, Beijing, China.

Novotný, J. and Kobr, M.: 2008, Hydrogeological pattern of groundwater flow of landslides in Cretaceous claystones based on long-term groundwater monitoring and hydrologging measurement. Environ. Geol., 58, 1, 25-32. DOI: 10.1007/s00254-008-1486-7

Pánek, T. and Klimeš, J.: 2016, Temporal behavior of deepseated gravitational slope deformations: A review. Earth-Sci. Rev., 156, 14-38.

DOI: $10.1016 /$ j.earscirev.2016.02.007

Pašek, J.:1964, Report on detailed geological research of landslide near Třebenice. Geological Institute, Czech Academy of Sciences, Praha, (in Czech).

Quitt, E.: 1971, Climatic regions of Czechoslovakia. Studia Geographica, 16, 73, Brno: Geografický ústav ČSAV, (in Czech).

Rybár, J: 1983, Report on detailed engineering geological research of landslides near Třebenice on the railway line Č́źžkovice - Obrnice. Ústav geologie a geotechniky ČSAV, Praha, (in Czech).

Rybáŕ, J. and Košták, B.: 2003, Monitoring and physical model simulation of a complex slope deformation in neovolcanites. In: Natau, O., Fecker, E., Pimentel, E. (Eds.): Geotechnical Measurements and Modelling. Swets \& Zeitlinger, Karlsruhe, 231-237.

Rybár, J.: 2007, The influence of climate on the development of different types of slope movements. Geoscience Research Reports in 2006, 90-92, (in Czech).

Strozzi, T., Klimeš, J., Frey, H., Caduff ,R., Huggel, C., Wegmüller, U. and Rapre, AC.: 2018, Satellite SAR Interferometry for the improved assessment of the state of activity of landslides: A case study from the Cordilleras of Peru. Remote Sens. Environ., 217, 111125. DOI: 0.1016/j.rse.2018.08.014

Urban, R., Štroner, M. and Balek, J.: 2016, Test of the precision and accuracy of the ShapeAccelArray sensor. Geoinformatics FCE, 15, 2, 43-58.

Vondráková, A., Vávra, A. and Voženílek, V.: 2013, Climatic regions of the Czech Republic. Journal of Maps, 9, 3, 425-430. DOI: $10.1080 / 17445647.2013 .800827$

Voráček, F.: 1991, Evaluation of stability conditions around Třebenice. Master thesis, Faculty of Science, Charles University, Prague, (in Czech).

Zoubek, V. and Škvor, V.: 1963, Explanations for geological map, scale 1:200,000, M-33-XIV, Teplice. ČSA, 260pp, (in Czech).

Zuzánek, B. and Vaněček, M.: 1982, Final Report of the engineering-geological survey: Section of the railway line Č́ižkovice - Obrnice km 6.6 -7.1 damaged by landslide, Geoindustria, n. p. Praha, Dubí u Teplic, (in Czech). 